\title{
PENGGUNAAN UMBI TALAS SEBAGAI BAHAN ADDITIVE TERHADAP BEBERAPA UNSUR KIMIA SILASE RUMPUT GAJAH MINI
}

\author{
Syamsuddin Nompo ${ }^{1 *}$ dan Rinduwati ${ }^{1}$ \\ ${ }^{1}$ Fakultas Peternakan Universitas Hasanuddin \\ J1. Perintis Kemerdekaan Km.10. Makassar, 90245 \\ *E-mail: syamsuddinompo05@gmail.com
}

\begin{abstract}
The aim of this experiment was conducted to investigate the effect of taro tuber flour to several chemical element of dwarf elephant grass silage. This experiment used dwarf elephant grass and taro tuber flour. The experiment was conducted according to completely randomized design consisting of 4 treatments and 4 replications. The treatment consisted of: $\mathrm{T} 0=$ dwarf elephant grass without taro tuber flour (control); $\mathrm{T} 1=$ dwarf elephant grass $+6 \%$ japan taro flour; $\mathrm{T} 2=$ dwarf elephant grass $+6 \%$ bogor taro flour; $\mathrm{T} 3=\mathrm{d}$ warf elephant grass $+6 \%$ silk taro flour. The results of this experiment indicated that the taro tuber flour significantly affected ( $\mathrm{P}<0,05$ ) to crude protein, crude fiber and ADF content, but did not significantly affect ( $\mathrm{P}>0,05$ ) the NDF content of dwarf elephant grass silage. The conclusion of this experiment that the crude protein content of dwarf elephant grass silage using taro tuber flour is higher than silage without taro tuber flour. The crude fiber content in the treatment without taro tuber flour is higher than the silage using taro tuber flour. The NDF and ADF silage content of dwarf elephant grass that used taro tuber flour is lower than silage without taro tuber flour. Silage that used silk taro tuber flour is better than other treatment.
\end{abstract}

Keyword: dwarf elephant grass, silage, taro tuber flour

\begin{abstract}
ABSTRAK
Penelitian bertujuan untuk mengetahui pengaruh umbi talas sebagai bahan additive terhadap beberapa unsur kimia silase rumput gajah mini. Penelitian ini menggunakan rumput gajah mini dan tepung umbi talas sebagai zat additive. Penelitian disusun berdasarkan Rancangan Acak Lengkap (RAL) sebanyak 16 unit percobaan, yang terdiri dari 4 perlakuan dan 4 kali ulangan. Perlakuan terdiri dari : T0 = Rumput gajah mini tanpa tepung umbi talas (control); T1 = Rumput gajah mini $+6 \%$ tepung umbi talas jepang; T2 $=$ Rumput gajah mini $+6 \%$ tepung umbi talas bogor; dan T3 = Rumput gajah mini $+6 \%$ tepung umbi talas sutra. Hasil penelitian menunjukkan bahwa pemberian tepung umbi talas berpengaruh nyata $(\mathrm{P}<0,05)$ terhadap kandungan protein kasar, serat kasar dan ADF tapi tidak berpengaruh nyata ( $\mathrm{P}>0,05$ ) terhadap kandungan NDF silase rumput gajah mini. Kesimpulan bahwa kandungan protein kasar silase rumput gajah mini yang menggunakan tepung umbi talas lebih tinggi daripada silase tanpa tepung umbi talas. Kandungan serat kasar pada
\end{abstract}


perlakuan tanpa tepung umbi talas lebih tinggi dibanding silase yang menggunakan tepung umbi talas. Kandungan NDF dan ADF silase dari rumput gajah mini yang menggunakan tepung umbi talas lebih rendah dibanding silase tanpa tepung umbi talas. Silase yang menggunakan tepung umbi talas sutra lebih baik daripada perlakuan lainnya.

Kata kunci: Rumput gajah mini, silase, tepung umbi talas

\section{PENDAHULUAN}

Produksi dan nilai nutrisi hijauan pakan yang tinggi merupakan salah satu faktor penentu keberhasilan suatu usaha peternakan khususnya ternak ruminansia. Di negara - negara tropis seperti Indonesia hal tersebut belum mampu dicapai mengingat pengaruh musim yang sangat mempengaruhi pertumbuhan dan produksi hijauan. Pada musim hujan produksi hijauan berlimpah dan mudah diperoleh, akan tetapi pada saat musim kemarau produksi hijauan sangat kurang bahkan banyak yang mengalami kekeringan sehingga bukan hanya kualitas hijauan yang sangat rendah akan tetapi kuantitasnya juga sangat tidak mencukupi kebutuhan ternak. Produksi biomassa hijauan yang rendah pada musim kemarau merupakan faktor penghambat utama yang mempengaruhi produksi susu sapi perah di Tanzania (Maleko et al., 2019).

Salah satu upaya yang dapat dilakukan Untuk mengatasi kekurangan hijauan pada musim kemarau khususnya di Indonesia adalah dengan melakukan penanaman hijauan yang berproduksi dan berkualitas tinggi untuk dapat memenuhi kebutuhan ternak. Rumput gajah dikenal sebagai hijauan tropis berproduksi tinggi, palatabel dan berkualitas tinggi (Ullah et al, 2010). Rumput gajah mempunyai peranan yang cukup besar di Negara-negara tropis dan subtropics, khususnya pada peternakan sapi perah (Simonetti et al., 2019). Produksi rumput gajah yang tinggi belum mampu mengatasi kekurangan hijauan pada musim kemarau yang panjang. Untuk itu cara terbaik mengatasi masalah tersebut adalah melakukan pengawetan hijauan pada saat produksi berlebih. Dari beberapa jenis rumput yang ada, rumput gajah merupakan rumput yang paling utama sebagai sumber pakan di padang penggembalaan selama musim kemarau dan sebagai bahan utama untuk produksi silase ( Dias et al, 2019 ).Bentuk 
pengawetan hijauan yang dapat dan mudah dilakukan adalah pengawetan dalam bentuk silase.

Salah satu upaya yang dapat dilakukan untuk mempercepat perkembangbiakan bakteri asam laktat dalam silo adalah pemberian zat aditif dari bahan yang mengandung karbohidrat tinggi. Bahan yang memiliki kandungan karbohidrat tinggi dan mudah diperoleh adalah umbi talas.

\section{METODE PENELITIAN}

Penelitian ini menggunakan Rancangan Acak Lengkap dengan 4 perlakuan (penambahan bahan pengawet tepung gaplek) dan 4 kali ulangan. Adapun perlakuan pemberian bahan pengawet adalah: $\mathrm{T} 0=$ Rumput gajah mini tanpa tepung umbi talas; $\mathrm{T} 1=$ Rumput gajah mini + tepung umbi talas jepang $6 \%$; T2 = Rumput gajah mini + tepung umbi talas bogor $6 \%$; T3 = Rumput gajah mini + tepung umbi talas sutra $6 \%$. Total perlakuan sebanyak 16 unit percobaan dan masing - masing perlakuan menggunakan rumput gajah mini yang telah di rajang/dicacah dan dilayukan sebanyak $2 \mathrm{~kg}$.

Tepung umbi talas yang digunakan diperoleh dari proses dengan cara: umbi talas di cuci bersih dan di kupas, selanjutnya diiris tipis - tipis untuk mempercepat proses pengeringan menggunakan sinar matahari selama 3 hari. Bahan tersebut selanjutnya digiling sampai menjadi tepung. Rumput gajah mini yang akan digunakan telah dirajang sepanjang $2 \mathrm{~cm}$ dengan kadar air sekitar $70 \%$. Rumput tersebut selanjutnya dicampur merata dengan tepung umbi talas sebanyak $120 \mathrm{~g} /$ silo, kecuali perlakuan kontrol. Bahan silase tersebut selanjutnya dimasukkan ke dalam silo dan ditutup rapat agar udara tidak masuk ke dalam. Silo dibuka setelah di peram selama 30 hari. Setelah sampai pada waktu yang ditentukan ( 30 hari ) selanjutnya silase dikeluarkan dari silo. Kemudian mengambil sampel sebanyak 200 g/silo untuk dianalisis di laboratorium. Untuk mengetahui kandungan protein kasar dan serat kasar dilakukan analisis laboratorium menggunakan metode analisis proksimat menurut AOAC (1992), sedangkan untuk mengetahui kandungan NDF dan ADF digunakan metode Van Soes ( 1992 ). 
Parameter yang diukur dalam penelitian ini adalah kandungan protein kasar, serat kasar, NDF dan ADF silase rumput gajah mini.

\section{HASIL DAN PEMBAHASAN}

Rata - rata komposisi kimia silase rumput gajah mini yang menggunakan bahan pengawet tepung umbi talas sutra dapat dilihat pada Tabel 1.

Tabel 1. Kandungan Protein Kasar, Serat Kasar, NDF dan ADF Silase Rumput Gajah Mini yang Menggunakan Bahan Pengawet Tepung Umbi Talas Sutra

\begin{tabular}{lcccc}
\hline \multirow{2}{*}{ Parameter } & \multicolumn{4}{c}{ Perlakuan } \\
\cline { 2 - 5 } & T0 & T1 & T2 & T3 \\
\hline Protein Kasar & $7,42^{\mathrm{a}}$ & $8,40^{\mathrm{b}}$ & $8,49^{\mathrm{b}}$ & $8,70^{\mathrm{b}}$ \\
Serat Kasar & $34,68^{\mathrm{c}}$ & $27,21^{\mathrm{ab}}$ & $28,17^{\mathrm{b}}$ & $24,55^{\mathrm{a}}$ \\
NDF & $63,12^{\mathrm{c}}$ & 57,26 & 55,45 & 54,69 \\
ADF & $44,38^{\mathrm{c}}$ & $38,87^{\mathrm{b}}$ & $38,75^{\mathrm{b}}$ & $33,46^{\mathrm{a}}$ \\
\hline
\end{tabular}

${ }^{\mathrm{abc}}$ superskrip yang berbeda pada baris yang sama menunjukkan perbedaan yang nyata $(\mathrm{P}<0,05)$.

Hasil analisis ragam menunjukkan bahwa pemberian bahan pengawet tepung umbi talas pada rumput gajah mini yang di silase memberikan pengaruh yang nyata $(\mathrm{P}<0,05)$ terhadap kandungan protein kasar dan serat kasar silase rumput gajah mini. Hasil Uji Beda Nyata Terkecil menunjukkan bahwa kandungan protein kasar silase rumput gajah mini pada perlakuan T0 berbeda nyata $(\mathrm{P}<0,05)$ lebih rendah dibanding dengan perlakuan T1, T2, dan T3. Sedangkan perlakuan T1, T2 dan T3 tidak terdapat perbedaan yang nyata ( $\mathrm{P}>0,05$ ).Kandungan protein kasar silase rumput gajah mini yang diperoleh pada penelitian ini berturut - turut dari terendah sampai tertinggi adalah ( $\mathrm{R} 0=7,42 ; \mathrm{R} 1=8,40 ; \mathrm{R} 2=8,49 ; \mathrm{R} 3=8,70$ ). Adanya perbedaan kandungan protein kasar antara perlakuan tanpa bahan pengawet dengan perlakuan yang mendapat tambahan bahan pengawet, mungkin disebabkan oleh aktivitas mikroorganisme yang terdapat pada perlakuan tanpa bahan pengawet hanya memperoleh sumber energy langsung dari hijauan yang ada sehingga kandungan nutrisi dari silase menurun termasuk protein yang ada pada silase tersebut. Sedangkan pada perlakuan yang diberi bahan pengawet ( T1, T2 dan T3 ) kandungan proteinnya lebih tinggi dibanding perlakuan tanpa bahan pengawet ( T0 ) hal ini 
mungkin disebabkan oleh karena bakteri yang ada memperoleh energi dari bahan pengawet yang ditambahkan pada hijauan tanpa banyak merombak hijauannya, sehingga unsur nutrisi termasuk kandungan protein yang ada pada silase tidak banyak mengalami perubahan. Hal senada dikemukakan oleh de Araujo et al. ( 2018 ) bahwa rendahnya kandungan protein kasar pada silase yang tidak diberi bahan pengawet dapat disebabkan oleh hilangnya beberapa kandungan nitrogen dapat larut selama penympanan.

Hasil Uji Beda Nyata Terkecil menunjukkan bahwa serat kasar silase rumput gajah mini pada perlakuan T0 berbeda nyata ( $\mathrm{P}<0,05$ ) lebih tinggi dibanding perlakuan P1, P2 dan P3. Tingginya kandungan serat kasar pada perlakuan tanpa tepung umbi talas mungkin disebabkan oleh meningkatnya persentase kandungan nitrogen yang hilang pada silase yang tidak menggunakan tepung umbi talas. Selain hal tersebut, tingginya kandungan serat kasar pada silase tanpa tepung umbi talas mungkin disebabkan oleh mikroorganisme yang ada lebih muda merombak unsurunsur isi sel dibanding dinding sel tanaman yang umumnya terdiri dari unsur serat. Berbagai penelitian menunjukkan bahwa pemberian bahan tambahan yang mengandung karbohidrat di dalam pembuatan silase pada umumnya meningkatkan kandungan protein kasar dan menurunkan kandungan serat kasarnya. Hasil penelitian Olorunnisomo ( 2011 ) menunjukkan bahwa kandungan protein kasar silase semakin menurun dengan bertambahnya persentase kulit ubi kayu dalam silase rumput gajah, sebaliknya kandungan serat kasarnya semakin menurun.

\section{Pengaruh Perlakuan Terhadap Kandungan NDF Dan ADF}

Hasil analisis ragam menunjukkan bahwa bahan pengawet tepung umbi talas

yang ditambahkan pada rumput gajah mini tidak memberikan pengaruh nyata $(\mathrm{P}>0,05)$ terhadap kandungan Neutral Detergent Fiber (NDF) silase rumput gajah mini. Data yang tertera pada Tabel 1. bahwa secara statistik menunujukkan tidak ada perbedaan yang nyata ( $\mathrm{P}>0,05$ ) antar perlakuan, akan tetapi silase dari rumput gajah mini yang dicampur dengan tepung umbi talas mengandung persentase NDF yang lebih rendah dibanding silase tanpa bahan pengawet tepung umbi talas. Hal ini 
kemungkinan disebabkan oleh adanya peningkatan lignin selama proses fermentasi sehingga dengan demikian akan menurunkan kandungan hemiselulosa. NDF dan ADF pada hijauan merupakan fraksi dinding sel dengan nilai cerna rendah ( Sudirman dkk. 2015 ). ADF mengandung sekitar $15 \%$ miceller pentose yang lebih sulit dicerna dibanding jenis karbohidrat lainnya ( Arora, 1989 ).

Neutral Detergent Fiber pada tanaman makanan ternak mengandung fraksi yang mudah larut yaitu hemiselulosa, sehingga degradasi NDF dalam rumen lebih tinggi dibanding degradasi ADF. Penurunan nilai NDF disebabkan oleh meningkatnya kadar lignin sehingga mengakibatkan menurunnya kadar hemiselulosa ( Sudirman dkk. 2015 ). Apabila tingkat keasaman dalam silase mencapai kondisi optimal untuk melonggarkan fraksi serat, maka ikatan hemiselulosa akan terdegradasi dan hemiselulosa larut dalam deterjen netral mengakibatkan kandungan NDF menjadi turun ( Senjaya dkk. 2010 ). Kadar lignin akan meningkat dengan bertambahnya umur tanaman. Selain itu semakin tua umur tanaman semakin rendah kandungan protein silase dan sebaliknya kandungan serat kasar meningkat dengan meningkatnya umur tanaman ( Syamsuddin ). Pada tanaman muda nilai nutrisi dan daya cerna akan lebih tinggi dibanding dengan tanaman tua. Hal ini disebabkan oleh tingginya kadar serat termasuk NDF dan ADF pada tanaman tua. Nilai NDF yang rendah pada silase menunjukkan nilai kualitas silase yang baik ( Senjaya dkk. 2010 ).

Hasil analisis ragam menunjukkan bahwa pemberian bahan pengawet tepung umbi talas berpengaruh nyata ( $\mathrm{P}<0,05$ ) terhadap kandungan ADF silase rumput gajah mini. Perlakuan T0 $(44,38)$ berbeda nyata $(\mathrm{P}<0,05)$ lebih tinggi daripada perlakuan T1 (38,87), T2 ( 38,75 ) dan T3 ( 33,46 ). Data tersebut menunjukkan bahwa pemberian zat aditif berupa tepung umbi talas dapat menurunkan kandungan ADF silase rumput gajah mini. Hal ini mungkin disebabkan oleh karena dengan adanya penambahan tepung umbi talas yang memiliki kandungan karbohidrat yang tinggi sehingga dalam proses ensilase mendorong bakteri cepat berkembang biak. Semakin banyak jumlah bakteri asam laktat dalam proses fermentasi akan semakin mempercepat terjadinya suasana asam dalam silo. Suasana asam yang disebabkan oleh fermentasi bakteri asam laktat akan mampu segera menurunkan suasana asam 
dalam silo. Silase yang dihasilkan merupakan silase yang berkualitas baik dan kondisi demikian akan dapat menurunkan kandungan ADF dan NDF yang ada pada hijauan yang disilase. Hal ini disebabkan oleh banyaknya jumlah bakteri yang ada sehingga semakin banyak dinding sel yang terdegradasi. Penurunan kandungan ADF pada silase dapat terjadi akibat adanya perombakan fraksi selulosa dari rumput gajah ( Senjaya dkk. 2010 ).

\section{KESIMPULAN}

Dari pembahasan data hasil penelitian ini dapat disimpulkan bahwa:

1. Kandungan protein kasar silase dari rumput gajah mini yang menggunakan tepung umbi talas lebih tinggi pada semua perlakuan dibanding silase tanpa teung umbi talas. Sedangkan kandungan serat kasar pada perlakuan tanpa tepung umbi talas lebih tinggi dibanding silase yang menggunakan tepung umbi talas.

2. Kandungan NDF dan ADF silase yang menggunakan tepung umbi talas lebih rendah dibanding silase tanpa tepung umbi talas.

3. Penggunaan tepung umbi talas sutra pada silase rumput gajah mini menghasilkan silase yang lebih baik dibanding silase yang tidak menggunakan tepung umbi talas Jepang dan umbi talas Bogor.

\section{DAFTAR PUSTAKA}

A.O.A.C. 1992. Official methods of analysis. Association of Official Analytical Chemists. Washington, DC.

Arora. 1989. Pencernaan Mikroba Rumen. Gajah Mada University Press. Yogyakarta.

De Araujo, R.A., R.C.Rodrigues, C.de S.Costa, F.N.S.Santos, C.M.L.Galvao, F.O.Costa, I.R. da Silva and S.da S.Mendes. 2018. Nutritive value and degradability "in situ" of dry matter elephant grass silages with addition of babassu meal. African Journal of Agricultural Research. vol.13(4), pp.2269 2274.

Dias, B.C.E., M.J.D. Candido, R.N.Furtado, R.C.F.F.Pompeu and L.V. da Silva. 2019. Nutritive value of elephant grass silage added with cottonseed cake in diet for sheep. Revista Ciencia Agronomica. v.50, n.2, p.321-328. 
Maleko, D., A.Mwilawa, G.Msalya, L.Pasape, and K.Mtei. 2019. Forage growth, yield and nutritional characteristics of four varieties of napier grass (Pennisetum purpureum Schumach) in the west Usambara highlands, Tanzania. Scientific African. volume 6, November 2019.

Olorunnisomo, O. 2011. Intake and digestibility of elephant grass ensiled with cassava peel by Red Sokoto goats. Tropentag. University of Bonn, Oktober 5-7, 2011. Conference on International Research on Food Security, Natural Resource Management and Rural Development.

Senjaya, O.T., T. Dhalika, A. Budiman, I. Hernaman dan Mansyur. 2010. Pengaruh lama penyimpanan dan aditif dalam pembuatan silase terhadap kandungan NDF dan ADF silase rumput gajah. Jurnal Ilmu Ternak. 10(2): 85 - 89.

Simonetti, G.D., C.J. Olivo, D.C. Seibt, V.F. Bratz, J.C. Sauthier and C.B. Adams. 2019. Productivity and nutritive value of elephant grass pastures under organic and conventional production systems. Anais da Academia Brasileira de ciencias.91 (2):e20180011.

Sudirman, Suhubdi, S.D.Hasan, S.H.Dilaga, dan I.W.Karda. 2015. Kandungan neutral detergent fibre (NDF) dan acid detergent fibre (ADF) bahan pakan local ternak sapi yang dipelihara pada kandang kelompok. Jurnal Ilmu dan Teknologi Peternakan Indonesia. volume 1 (1) : 66-70.

Syamsuddin, 2013. Pengaruh pupuk organic dan umur defoliasi terhadap beberapa zat gizi silase rumput gajah. Buletin Nutrisi dan Makanan Ternak. 9 (1): 9-17.

Ullah, M. A., M.Anwar and A.S.Rana. 2010. Effect of nitrogen fertilization and harvesting intervals on the yield and forage quality of elephant grass (Pennisetum purpureum) under mesic climate of Pothowar Plateau. Pakistan Journal .Agri. Sci., 47(3), 231-234. 